\title{
Kaposi's Sarcoma: clinical and pathological aspects in patients seen at the Hospital Universitário Cassiano Antônio Moraes - Vitória - Espírito Santo - Brazil *
}

\author{
Sarcoma de Kaposi: achados clínico-patológicos nos pacientes atendidos no
} Hospital Universitário Cassiano Antônio Moraes - Vitória - Espírito Santo - Brazil

\author{
Ricardo Montibeler Tiussi ${ }^{1}$ \\ Lucia Martins Diniz ${ }^{3}$
}

\author{
Antonio Luiz de Oliveira Caus ${ }^{2}$ \\ Elton Almeida Lucas ${ }^{4}$
}

\begin{abstract}
BACKGROUND: Kaposi's sarcoma is a neoplasm of endothelial origin that is divided into four distinct types according to the clinical characteristics and the affected population: Classic (in elder men of Jewish or Mediterranean origin); Epidemic (in patients affected by AIDS); Endemic (in black African men) and Iatrogenic (in patients under immunosuppressive regimens). Human herpesvirus 8 infection is essential but not sufficient for the sarcoma development.

OвJECTIVE: To describe the epidemiological, clinical and histopathological aspects of patients with KS seen at the Dermatology Clinic Cassiano Antônio Moraes University Hospital - Federal University of Espirito Santo, Vitória - ES.

METHODS: A descriptive and retrospective study based on clinical charts of patients with KS seen at the Dermatology Clinic from 1986 to 2009. Results: The majority of the 15 cases were male patients (93,3\%) and white (60\%). Epidemic Kaposi's sarcoma occurred in $80 \%$, and the Classic form in $20 \%$, with no cases in the Endemic or Iatrogenic groups. All the histopathological exams of the cutaneous lesions were reviewed and a proliferation of fusiform cells, extravasated erythrocytes and vascular rifts among the largest vessels, assuming the "vessels in vessels" typical aspect, were seen.

Conclusion: The number of cases of Kaposi's Sarcoma was linear throughout the years of the study, especially of the epidemic form, although the incidence and prevalence of AIDS increased in the state of Espírito Santo. Therefore, if we consider the relation between KS and AIDS, a decreasing line of Kaposi's sarcoma could be seen, especially after the introduction of HAART.

Keywords: AIDS Serodiagnosis; Epidemiology; HIV antigens; Herpesvirus 8, human; Sarcoma, Kaposi
\end{abstract}

Resumo: FunDAMENTOS: O Sarcoma de Kaposi é neoplasia de origem endotelial, dividida em quatro formas clínicas: clássica (homens idosos de origem judaica e mediterrânea), epidêmica (associada ao HIV), endêmica (negros africanos) e iatrogênica (relacionada à imunossupressão). A infecção pelo herpes vírus humano tipo 8 (HHV-8) é necessária, mas insuficiente para que todas as formas possam ocorrer.

OвJETrvos: Avaliar os aspectos epidemiológicos, clínicos e características histopatológicas das lesões dos pacientes com Sarcoma de Kaposi consultados no Serviço de Dermatologia do Hospital Universitário Cassiano Antônio Moraes - Universidade Federal do Espírito Santo, Vitória - ES.

MÉToDos: Estudo retrospectivo, descritivo, realizado pela análise dos prontuários dos pacientes diagnosticados com Sarcoma de Kaposi, durante janeiro de 1986 a dezembro de 2009, no Serviço de Dermatologia. Resultados: Dos 15 pacientes estudados, houve maioria do sexo masculino $(93,3 \%)$ e predomínio da raça branca $(60 \%)$. A forma epidêmica foi a mais freqüente $(80 \%)$, seguida pela clássica (20\%). Não foram observadas as formas: endêmica e iatrogênica. A revisão das lâminas das biópsias cutâneas foi feita nos 15 casos, e demonstrou derme com proliferação de células fusiformes, extravasamento de hemácias e fendas vasculares em torno de vasos maiores, com aspecto clássico de "vasos em torno de vasos".

Conclusões: O número de casos de Sarcoma de Kaposi foi linear ao longo do estudo, especialmente da forma epidêmica. Por outro lado, a incidência e a prevalência da AIDS no Espírito Santo foram crescentes. Portanto, considerando-se a relação entre o sarcoma de Kaposi e a AIDS houve decréscimo do primeiro, mais acentuado após a era HAART.

Palavras-chave: Antígenos HIV; Epidemiologia; Herpesvirus humano 8; Sarcoma de Kaposi; Sorodiagnóstico da AIDS

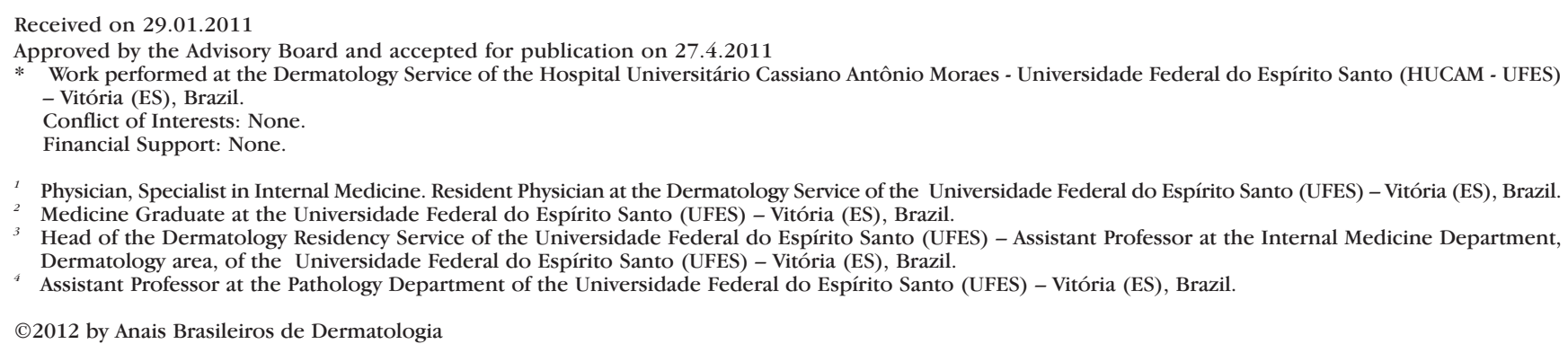




\section{INTRODUCTION}

Kaposi's sarcoma (KS) is a malignant neoplasia, described by Moritz Kaposi in 1872. It originates from the endothelium and it is a low grade malignancy, considered rare until the discovery of the Acquired Immunodeficiency Syndrome (AIDS). Currently four clinical presentations are recognized: classic, endemic, epidemic and iatrogenic. Despite the fact that each of them has a distinct progress, they all have in common the participation of the human herpes virus type 8 (HHV-8) or the Kaposi's sarcoma associated herpes virus (KSHV), although other factors are necessary for the occurrence of the disease. ${ }^{1}$ The prevalence of the HHV-8 is low in the United States and the United Kingdom (zero to 5\%), intermediate in Italy and Greece (30\%) - Mediterranean countries - and high in central Africa (more than $50 \%$ in Uganda).

Currently, the physiopathology of KS is based on three pillars: HHV-8, cytokine release and HIV tat gene. ${ }^{3}$

The HHV-8 encodes many homologues of the human genes that are involved in inflammation, cell cycle regulation and angiogenesis, such as viral cicline-D1, vascular endothelial growth factor, fibroblasts basic growth factor and interleukine-6. It inhibits the host's immune response and block some tumor suppressor proteins, amongst them the $\mathrm{p} 53$. The most important gene of the latent HHV-8 is the ORF73 which encodes the LANA or LAN-1, an antigen used for preventing the presentation of the histocompatibility antigen (HLA) by the infected cells, this way fooling the immune system. The HIV tat gene encodes the Tat-1 protein, which increases the activity of different cytokines and angiogenic factors, amplifying the "tumorigenic" signals. ${ }^{3}$

The origin of the fusiform cells, a marker for the $\mathrm{KS}$, is not completely understood. Most research favors a lymphatic endothelial cell, and the reactivity of two monoclonal antibodies: EN4 e PAL E corroborates this. However, the fusiform cells express the CD34 antigen, a glycoprotein expressed by endothelial cells of small blood vessels, not expressed by cells of lymphatic origin. ${ }^{3}$

The HHV-8 is the most common cause of malignant lesions in patients with AIDS, and its transmissibility is widely discussed. It is known, however, that the transmission via saliva is becoming greatly important over the last years. This via predominates in endemic countries and among susceptible individuals in countries with low prevalence, and is also the probable transmission means amongst family members of the patients with classic KS in Mediterranean areas. In indigenous tribes of the Amazon the HHV-8 is fund in 18 to $30 \%$ of the children and in 40 to $80 \%$ of the elderly, and the salivary acquisition is facilitated by the poor hygiene habits and the crowded way of living. The sexual via is the most important one among immune competent individuals in areas with low prevalence of the HHV-8, and the male homosexuals are more susceptible, as the trauma from unprotected intercourse facilitates the viral transmission. ${ }^{4}$ The transmission amongst drug users is rare. ${ }^{4}$

The classic KS is seen in white men from Eastern Europe and the Mediterranean over 60 years old (90\% of the cases) and is not related to HIV infection. The disease initiates as violaceous or reddishbrown maculae and papules on the hands and feet, progressing to the arms and legs (most common site) over the years. In $10 \%$ of the cases there is the involvement of viscera and mucosa. ${ }^{5}$

The endemic KS is divided into two subtypes: the first develops in middle age adults (25 to 50 years old) who live in Sub-Saharan Africa and has only local aggressiveness. The second one develops mainly children from the "Bantu" ethnicity less than 10 years old. It is characterized by generalized lymphadenopathy and has an aggressive clinical behavior, killing within two years after the diagnosis. ${ }^{6}$

The KS associated with immunosuppressive states develops mainly in solid organs transplant receivers, but also in those with neoplastic diseases and those with autoimmune conditions under immunosuppressive treatment. The clinical and morphological aspects are similar to the classic form. The suspension of the immunosuppressive treatment usually causes the regression of the lesions, but increases the risk of losing the transplant.

AIDS was described in 1981, in patients where the Kaposi's Sarcoma was the main element of the syndrome, observed in 30 to $40 \%$ of them. This form develops predominantly in homosexuals and bisexuals, being rare in injectable drug users and heterosexuals. Due to the changes on the sexual behavior and the antiretroviral drugs, its frequency went from $40 \%$ at the beginning of the 90ties to $15 \%$ nowadays. The lesions start as small, non-itchy, slightly painful, violaceous patches on the face, trunk, limbs and oral mucosa, with subsequent progression to plaques and nodules. Visceral lesions are frequent and gastrointestinal and pulmonary involvements are common. ${ }^{8}$

The diagnosis of KS is based on the clinical findings and the histopathological exam. Detection of the HHV-8 LANA-1 antigen can be useful in dubious cases. Serologic tests for the detection of the LANA-1 are promising; image exams can be used to observe internal lesions, like computerized tomography for pulmonary foci and high digestive endoscopy or colonoscopy for gastrointestinal involvement. ${ }^{3}$ 
The study aimed at knowing the epidemiological profile, the clinical forms and the histopathological abnormalities of KS among the patients seen at the Dermatology and Dermatopathology Service of the Hospital Universitário Cassiano Antônio Moraes, for the period of January 1986 and December 2009.

\section{PATIENTS AND METHODS}

Retrospective, descriptive study, through the analysis of the medical charts of patients diagnosed as having KS, through the archives of patients who underwent cutaneous biopsy and the clinical-pathological discussion, for the period of January 1986 to December 2009, on the Dermatology Service of the Hospital Universitário Cassiano Antônio Moraes (HUCAM). The study also included the patients who attended the Dermatopathology sessions, held once a week at the Pathology Service of the HUCAM, where the dermatological diseases considered of highest academic interest or highest diagnostic difficulty are discussed, from the clinical-pathological point of view. Ten cases are discussed per session and the data is filled, and is available at the Dermatology Service of the Hospital.

Data referring to epidemiology, clinical manifestations, associated disease and treatments instituted and well as the clinical response to the treatment were recorded.

For the analysis of the histopathological characteristics of the biopsies of cutaneous lesions a search for all the slides and/or blocks from patients with a diagnosis of KS was requested, so that they could be revised and all the alterations that favored the diagnosis of the dermatosis were recorded.

The variables (age, sex, race, types of KS and histopathological aspects of the biopsied lesions) were analyzed with the statistical program SPSS 13.0, and their frequencies, concordance between the clinical and the histopathological diagnosis and the level of significance $(p \leq 0,05)$ amongst the variables were determined.

The study Project was approved by the Research Ethics Committee of the Health Sciences Center in December 2009, under the registration number 209/09.

\section{RESULTS}

After the analysis of the archives of the Dermatology Service of HUCAM, 22 cases with the diagnosis of KS by clinical-histopathological assessment were found, amongst the 5.581 patients submitted to the same analysis, from the period of January 1986 to December 2009, representing a frequency of $0,39 \%$ of the total number of cases discussed at the dermatopathology sessions.

From the twenty-two medical charts, seven were not entered into the study, as they were not made available by the Medical and Statistical Service of the hospital, due to their inexistence on the sector. This way, the retrospective study was based on the analysis of 15 medical charts, and the histopathological revision of the slides from cutaneous biopsies was possible for all the 15 cases.

The diagnosis of KS requires clinical-pathological concordance. According to the clinical classification of the patients, from the 15 studied, 12 corresponded to the epidemic form and three to the classic form (Figures 1, 2 and 3). There were no cases with the iatrogenic or endemic forms. From the 15 patients submitted to the histopathological analysis, all were compatible with KS (Figures 4, 5 e 6).

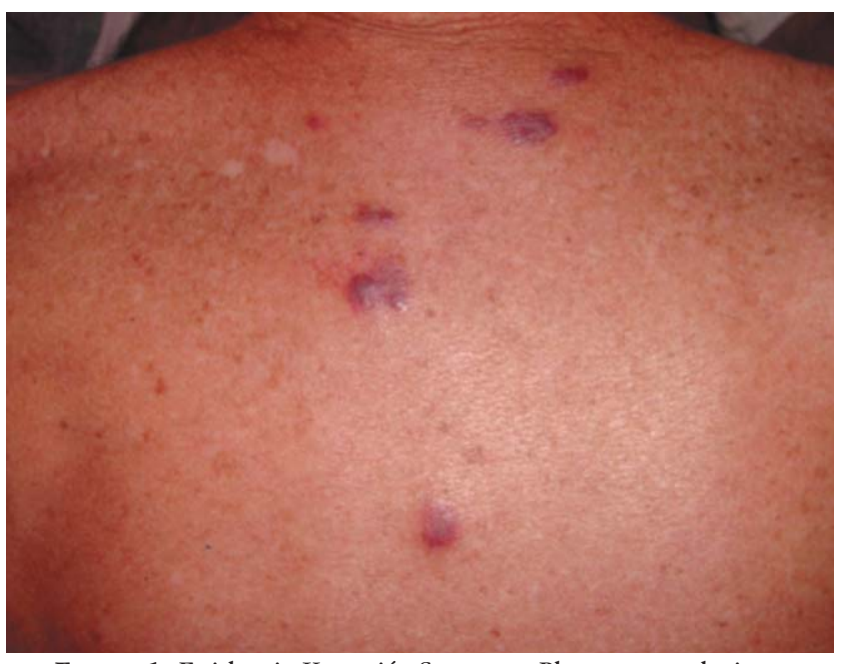

Figure 1: Epidemic Kaposi’s Sarcoma. Plaque stage lesions

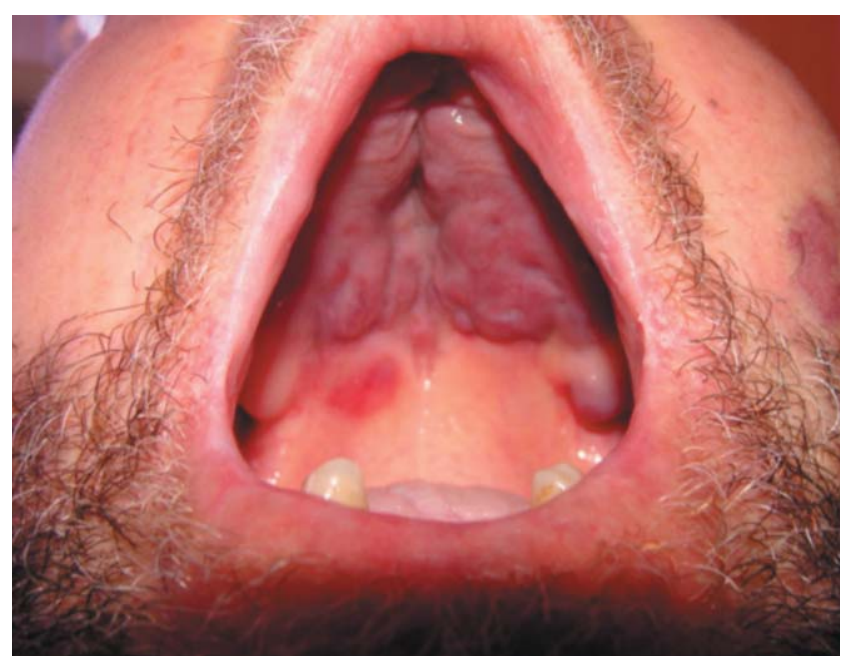

Figure 2: Epidemic Kaposi's Sarcoma. Tumoral, infiltrated lesion on the hard palate 


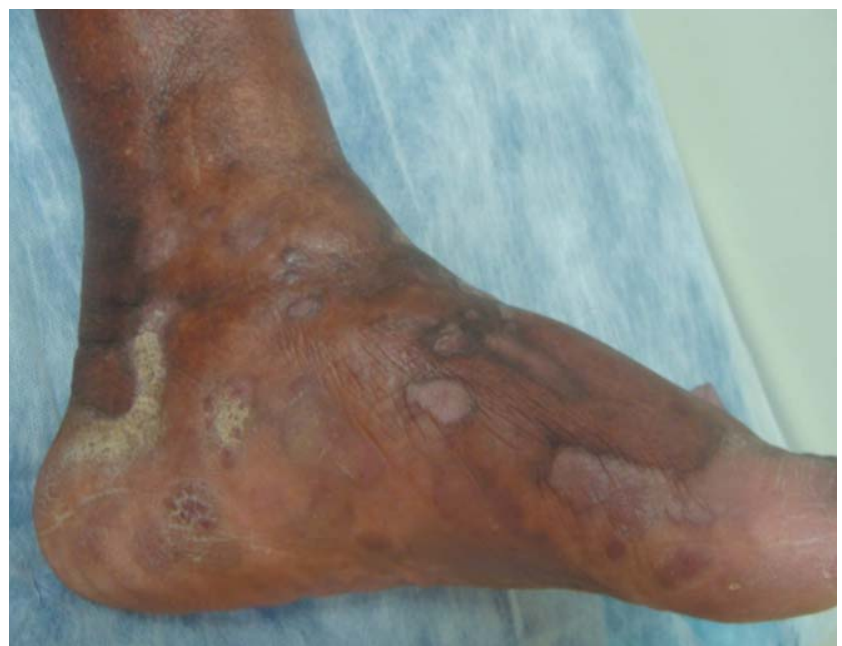

Figure 3: Classic Kaposi's Sarcoma. Violaceous plaques on the medial region of the left foot.

In terms of epidemiology, 14 patients $(93,3 \%)$ were male and one $(6,7 \%)$, on the epidemic group, female; nine were white (eight on the epidemic group and one on the classic KS group) and six had dark skin (four on the epidemic group and two on the classic KS group).

The age of the patients varied from 20 to 90 years, with a median of 34 years and 5 months (standard deviation of eight years and one month) for the epidemic group and 86 (standard deviation of eleven years and one month) for the patients with the classic form (Figure 3).

On the first consultation the diagnostic suspicion of KS was made in eleven cases, while in three of them there were the following hypothesis: fibroma, leprosy, histoplasmosis, cryptococcosis, bacillary angiomatosis and, as a second option, $\mathrm{KS}$; in one case there was no report of a diagnostic hypothesis on the medical chart.

Clinically, the cutaneous lesion found varied as patches, plaques and nodules. The locations were: head and neck (3/15), head, neck and limbs (2/15), head and trunk (2/15), lower limbs (3/15), upper and lower limbs (2/15) and disseminated form (3/15).

Visceral involvement was seen in five (33\%) patients, four with the epidemic form and one with the classic form. The distribution was as follows: intestine (1/5), lungs (1/5), lungs and stomach (1/5), lymph nodes $(1 / 5)$ and liver (1/5). It is important to highlight that the patient with lymph nodal SK had the classic form, where the extra-cutaneous location occurs in only $10 \%$ of the cases.

In terms of the viral load (VL) and the $\mathrm{CD}^{+}{ }^{+} \mathrm{T}$ lymphocytes count on the epidemic form, the notes were recorded in three cases for the VL and in five for the $\mathrm{CD}^{+}$, making any type of statistical analysis impossible.

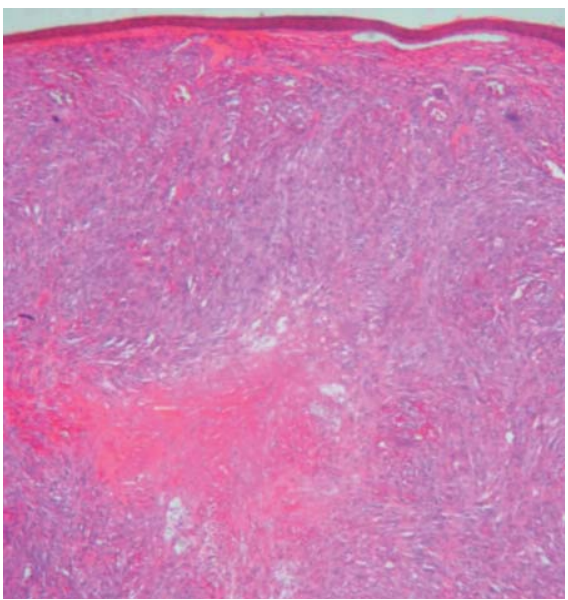

FIGURE 4: Massive infiltration of fusiform cells and thinning of the epidermis (nodule stage)

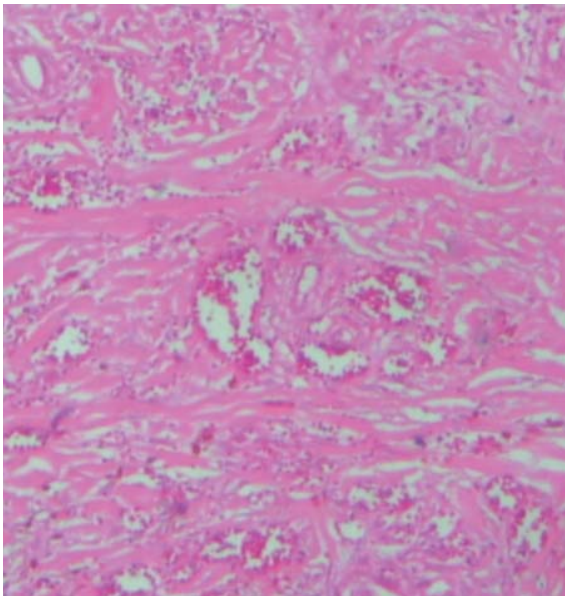

Figure 5:

Promontory sign.

"Vessels around newly formed vessel"

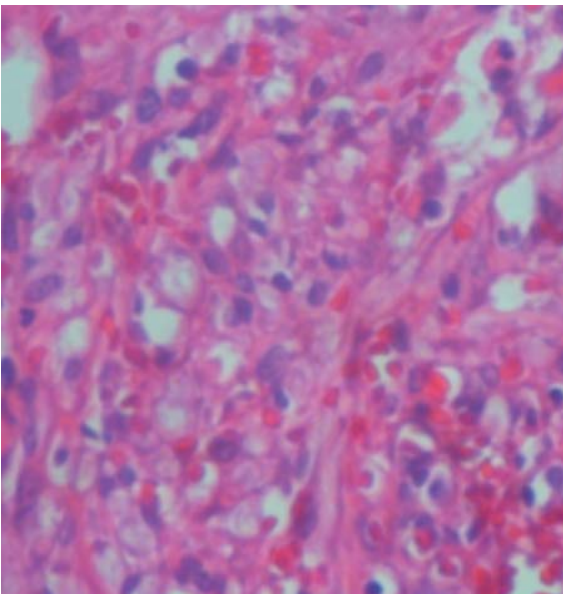

Figure 6:

Hyalin corpuscles

Co-morbidities were observed in 13 patients, ten with the epidemic form and three with the classic form. All the opportunistic infections and neoplasias were seen in patients with the epidemic KS, distributed as follows: neural criptococcosis (1/10), NonHodgkin lymphoma (1/10), nocardiosis and pulmonary tuberculosis (1/10), oral/esophageal candidiasis (3/10), hepatitis B and pulmonary tuberculosis (1/10), neural toxoplasmosis $(1 / 10)$, oral/esophageal candidiasis, ganglionic tuberculosis and neural toxoplas- 
mosis (1/10). And the patients with the classic form had the following chronic-degenerative diseases: high blood pressure, diabetes mellitus, dyslipidemia, congestive cardiac failure and chronic obstructive pulmonary disease.

As for the laboratory findings, anemia (hemoglobin lower than $13 \mathrm{~g} / \mathrm{dl}$ for males and $12 \mathrm{~g} / \mathrm{dl}$ for females) was seen in seven patients (six with the epidemic form), leukopenia (total leukocytes below 4.000 cells $/ \mathrm{mm}^{3}$ ) in one case with the epidemic form, anemia associated with leukopenia in three cases with epidemic KS, and hyperglycemia (fasting glucose level over $100 \mathrm{mg} / \mathrm{dl}$ ) in one case, associated with the classic KS. Monocytosis and eosinophilia were not observed.

In terms of the histopathological analysis, from the 15 slides revised all had the diagnosis of KS with the use of hematoxylin and eosin staining, and immune histochemical analysis were not necessary. The authors found six patients with lesions in the form of spots, six as plaques and three in the form of nodules.

The basis to the histological classification of the lesions in patch, plaque or nodule was the group of findings from each piece studied. On the patch stage the presence of vascular clefts parallel to the epidermis, around the vascular plexus located on the papillary dermis and small number of fusiform cells amongst the bundles of collagen fibers were observed. The extravasations of red blood cells were frequent, a feature common to all stages. On the plaque lesions the vascular proliferation and the infiltration of fusiform cells were more prominent, reaching up to the reticular dermis. The latter, however, did not form fascicles. The presence of the "promontory sign", where "spaces" are created around pre-existent vascular structures, was also frequent (Figure 5). At this stage the cytoplasm of the fusiform cells can show small spaces occupied by degenerated red blood cells, called hyaline globules or hyaline corpuscles (Figure 6). At last, the authors characterized the nodule stage according to the findings: massive infiltration of fusiform cells involving all the dermis, thinning the epidermis and forming bundles that intercrossed among themselves (Figure 4 ). The vascular spaces were "trapped" among the fusiform cells and took on the aspect of a "sieve". Another fact that corroborated the nodule stage was the great number of mitosis, implying advanced stage neoplasia.

On the epidemic KS group, the most commonly used therapy was the HAART, isolated in one patient and associated with chemotherapy in three (20\%). On the classic form one patient underwent radiotherapy and another received thalidomide. Three patients did not receive any treatment, one with the classic form and two with the epidemic.
The number of cases with epidemic KS along the 23 years of the study remained constant, around zero to two cases/year, making up a total of 12 cases. On the other hand, the incidence and the prevalence of AIDS on the Espírito Santo increased a lot over those years, and only started to decrease from 2005 . If we compare the ratio KS/AIDS, there was a decrease, even more pronounced after the HAART era (Graph 1).

There was no significant statistical difference when comparing the types of KS and sex $(p=1,000)$, race $(p=0,525)$, presence of co-morbidities $(p=0,200)$ and extra-cutaneous involvement $(p=1,000)$. The statistical significance was evidenced when comparing the types of KS: epidemic and HIV positive group and classic and HIV negative group $(p=0,002)$ and the age of onset, up to 50 years on the first group and over 60 years on the second group, with $p=0,002$.

\section{DISCUSSION}

On the study we found 15 vases of KS among the 5.581 patients who attended the Dermatopathology sessions, over a period of 23 years, which constitutes a sample smaller than the one reported on the literature, since the epidemic form itself develops in around 15\% of the patients with AIDS and, in the Espírito Santo, approximately 6.200 cases of AIDS were notified during this period. 3,9 However, it is important to consider that the number of cases found on the Dermatology Service of HUCAM corresponds to the patients that attended the Dermatopathology sessions, and not to the total number of cases of the disease seen by other specialists in the hospital.

The disease was more frequent in males (14:1), corroborating the data from the literature, which describes the predominance of men in all the clinical forms, especially on the epidemic, where homosexuals and bisexuals are the most afflicted. ${ }^{10}$ The isolation of the HHV-8 provided an explanation for this

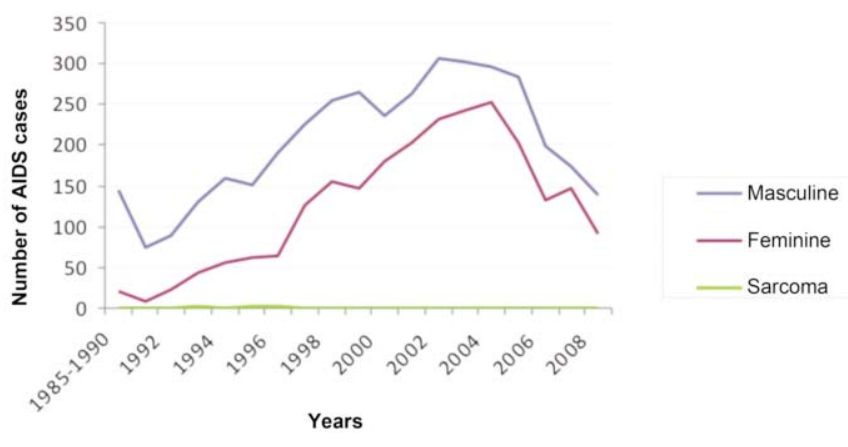

GRAPH 1: Chart showing the number of AIDS cases, according to year of diagnosis, by sex, on the State of Espírito Santo, between 1985 and 2008, in relation to the number of cases of Kaposi's Sarcoma at the HUCAM 
fact, associated with the protective effect of the feminine hormone LH on the development of KS in women. ${ }^{6}$

The study showed a median age of 34 years and five months for the epidemic form and 86 years for the classic form, and the age incidence peak for the former was between 20 and 40 years and most patients on the latter form were 60 years or older, which corroborates the data from the literature. ${ }^{3}$

In this study, most patients were white. National data is scarce, but in the United States KS is rare in Negroes. On the other hand, the frequency of the disease is high in certain black populations (subSaharan) in Africa. ${ }^{3}$ It is known that the KS, in its classic form, is almost exclusive to white men. A curious fact is that two of the three patients who had the classic form were brown skinned. An explanation for this is maybe the high rate of racial miscegenation in Brazil.

During the first consultation, the most commonly formulated diagnostic hypothesis was KS, since the majority of the patients presented with lesions in the form of plaques or nodules, making the diagnosis easy. On the other hand, the early lesions presenting as patches did not so promptly led to the consideration of the disease. According to the literature, the main differential diagnosis are: acroangiodermatitis, multinucleate cells angiohistiocytoma, pyogenic granuloma, melanoma, bacillary angiomatosis, sclerosing hemangioma type dermatofibroma, amongst others. ${ }^{11}$ The two last ones were differential diagnosis considered in few patients of the study.

In relation to the clinical type of the lesions, there were no reports on the clinical charts as to which ones prevailed. The estimate that plaques and nodules comprised most of the cases was made based on the histopathological findings. The lesions presenting as patches are always initial, plaques would indicate an intermediate progression while nodules are found in patients with disease of longer duration. ${ }^{12}$ However, some authors classify the KS lesions as patches, plaques, nodules and tumors, in increasing order of progression, and the tumors are associated with important immune suppression states. ${ }^{13}$

The locations of the cutaneous lesions were, in decreasing order of frequency: head and neck, lower limbs, and cutaneous disseminated. The location on the lower limbs is more characteristic of the classic form of KS. In the study, all patients with this variant presented with lesions on the legs. The highest number of lesions located on the head and trunk was justified by the predominance of the epidemic form, also described by Sampaio et al. ${ }^{5}$ On the other hand, some authors have observed a random distribution of the lesions in this clinical form. ${ }^{6}$ Genital lesions were not found in the study, however this is s frequent location of epidemic KS. The cutaneous disseminated form was found exclusively in patients with the epidemic form, developing in advanced stages of immune suppression, mainly in those not submitted to the HAART. ${ }^{14}$

It is important to stress that the patient with lymph nodal KS had the classic form of the disease, where the extra-cutaneous location develops in $10 \%$ of the cases. ${ }^{5}$ Those with visceral and cutaneous disease resort to oncologists and infectious diseases specialists, which could explain the reduced number of patients on the study.

Most patients had exclusive cutaneous involvement (10/15). In those with visceral disease there was a balance between the gastrointestinal and the pulmonary forms, although the literature reports the digestive system involvement in up to $40 \%$ of the cases at the initial diagnosis and in up to $80 \%$ in autopsies. ${ }^{14}$ Visceral disease can occur without cutaneous participation. ${ }^{15}$

The finding of chronic-degenerative diseases in the patients with the classic form is explained by the age group they belong to (over 60 years), and systemic high blood pressure, diabetes mellitus, dyslipidemia and chronic obstructive pulmonary disease are common at this age, although an increased incidence of diabetes has been described on the classic KS. ${ }^{15}$

With respect to opportunistic infections and neoplasias associated with immune suppression, all of them were observed in the patients with the epidemic form, explained by the effects of the HIV on the immune system. In decreasing order of frequency, the infections were: oral/esophageal candidiasis, neural toxoplasmosis, pulmonary tuberculosis, ganglionic tuberculosis, neural criptococcosis, pulmonary nocardiosis and hepatitis B. Burkitt lymphoma (non-Hodgkin lymphoma) was diagnosed in one patient. The literature still highlights the high incidence of Pneumocystis jiroveci (carinii) pneumonia in this population. However, the isolation of this agent is difficult to obtain, which justifies the sub-notification of the entity and the empirical treatment of patients with cough and chest $\mathrm{X}$ ray abnormalities. ${ }^{16}$

Data on viral load and $\mathrm{CD}^{+}$from the patients with the epidemic form were not recorded on most of the medical charts researched. Some were due to the irregular follow up at the infectious disease service, others by the fact that the diagnosis of the infection by the HIV was done during hospitalization for the treatment of co-morbidities. In these cases, the viral load count and the $\mathrm{CD}^{+}$dosage are not immediately performed, as they are altered by opportunistic infections and by the drugs used in their treatment. ${ }^{17}$ The immune reconstitution syndrome, which was not found in this study, is characterized by worsening of previous 
lesions and the development of new lesions of KS, after improvement of the immune status by the HAART. Its incidence varies around $7 \%$ and it develops within the first two months of beginning the antiretroviral therapy. ${ }^{17}$

Leukopenia and anemia were found predominantly on the epidemic form, justified by the cytopenia of one or more blood lineages caused by the HIV. Anemia can also be secondary to gastrointestinal tract or pulmonary bleeding. Of the patients with the classic form, most had normal laboratory exams, due to the lower aggressiveness of the KS. ${ }^{11}$ The only case with hyperglycemia had the classic form, maybe due to the higher prevalence of this abnormality in this particular age group. However, the literature describes increased incidence of diabetes in classic KS. ${ }^{15}$

In regards to the histopathological analysis, it was not possible to draw a parallel with the cutaneous lesions, as the records about the clinical forms were insufficient. However, the histopathological findings varied from patches to nodules. Corroborating the literature, there was no finding that could characterize, without doubt, a particular type of lesion. Neither the clinical type of KS could be determined, since the histopathology is similar in all forms. Maybe only one characteristic, the finding of cytoplasmic inclusion in the fusiform cells, could be suggestive of epidemic KS. ${ }^{10}$ One finding, however, found in all stages of KS and characteristic of the neoplasia, is the presence of "vessels around vessels", present in all the slides studied.

Due to the predominance of cases of epidemic KS, the, HAART therapy prevailed. From the twelve patients with epidemic KS, seven were prescribed or had already been submitted to the therapy against the HIV and three were submitted to the association of HAART with chemotherapy. For those, the chosen chemotherapy drug was vincristine, isolated or in association with cyclophosphamide and dexamethasone. In one patient, the chemotherapeutic drug used was not mentioned; in another the therapeutic modality was not cited. Another case of epidemic KS did not receive treatment as chemotherapy was indicated but not performed due to an associated infectious disease. The only case treated with radiotherapy was from the classic KS group and had lesions on the lower limbs and soles. The literature stresses that recent lesions from the classic KS respond well to radiotherapy. One patient from this group received treatment with thalidomide (50 to $200 \mathrm{mg} /$ day), with relief of the pain and edema on the lower limbs, as well as partial regression of the lesions. The third patient with classic KS did not receive any treatment for the neoplasia, a conduct that is backed by the literature, especially for the classic form, when there are no important complaints in terms of pain, aesthetic damage or associated visceral disease. ${ }^{18}$

Many authors describe a dramatic decrease on the incidence of epidemic KS after the middle of the $90^{\text {ties }}$, in the United States and in Europe, the time when the HAART started to be used. The authors from the present study observed similar facts, as the number of AIDS cases on the state increased during the period studied, while the frequency of KS was linear, and it can be deduced that the relationship between KS and the population of patients with AIDS, in the Espírito Santo, was descending. However, data pertinent to epidemic KS in the state were not found.

\section{CONCLUSIONS}

From the study:

1 - The authors did not observe a drop in the frequency of epidemic KS after the HAART era on the patients from the Dermatology Service of the HUCAM/UFES. However, when considering the relationship between the disease and the population with AIDS on the state of Espírito Santo, it was descending.

2 - The epidemic KS responded to $80 \%$ of the cases and the classic form to $20 \%$ of the patients studied. The iatrogenic and endemic forms were not observed.

3 - There was absolute predominance of the neoplasia on the male population.

4 - The epidemic form was more common among young adults, and the classic one in patients over 60 years of age.

5 - On the classic KS most patients had brown skin and one had a case of extra-cutaneous disease.

6 - The histopathological exam was enough to confirm the diagnosis, dispensing the immune-histochemical analysis of cutaneous lesions. The characteristic finding of "vessels around vessels" was present in all the slides studied. $\square$ 


\section{REFERENCES}

1. Ohe EMDN, Padilha MHVQ, Enokihara MMSS, Almeida FA, Porro AM. Sarcoma de Kaposi classico fatal. An Bras Dermatol. 2010;85:376-9.

2. Lebbé C. Human Herpesvirus 8 as the infectious cause of Kaposi Sarcoma. Arch Dermatol. 1998:134:736-8.

3. Schwartz RA, Micali G, Nascar MR, Scuderi L. Kaposi sarcoma: a continuing conundrum. J Am Acad Dermatol. 2008:59:179-206.

4. Pica F, Volpi A. Transmission of human herpesvírus: an update. Curr Opin Infect Dis. 2007;20:152-6.

5. Sampaio SAP, Rivitti EA. Dermatologia. São Paulo: Artes Médicas; 2008. p.1218-21. (Capitulo 78, Tumores e malformações vasculares).

6. Szajerka T, Jablecki J. Kaposi's sarcoma revisited. AIDS Rev. 2007:9:230-6.

7. Rutowitsch MS, Esporcatte AP. Sarcoma de Kaposi. An Bras Dermatol. 1995;70: 347-56.

8. Santos OLR, Rodrigues AG, França ER, Coelho APG, Carneiro SCS. Os herpervirus humanos no curso da síndrome de imunodeficiencia adquirida. An Bras Dermatol. 1998;73(Supl. 2):10-8.

9. saúde.es [Internet]. Secretaria estadual de saúde do Espirito Santo (SESA). Situação epidemiológica da AIDS - Estado do Espírito Santo - Dados acumulados até DEZ/2008. [acesso 15 Abr. 2010]. Disponivel em: www. saude. es. gov. br/.../ Dados_Epidemiologicos_AIDS_Dez_08.doc

10. Antman K, Chang Y. Kaposi's Sarcoma. N Engl J Med. 2000; 342:1027-38.

11. Rapini RP. Proliferações e neoplasias vasculares. In: Rapini RP. Dermatopatologia prática. Rio de Janeiro: Dilivros; 2007. p.329-32.

12. McKee PH. Kaposi's Sarcoma. In: McKee PH. Pathology of the skin: with clinical correlations. 2nd ed. Philadelphia: Mosby; 1996. p.68-71.

13. Calonje E, Wilson-Jones E. Vascular Tumors. In: Elder DE, Elenitsas R, Johnson Jr B, Murphy GF, Xu X. Lever's Histopathology of the skin. 10th ed. Philadelphia: Lippincott Williams \& Wilkins; 2009. p.1029-35.
14. Di Lorenzo G, Konstantinopoulos PA, Pantanowitz L, Di Trolio R, De Placido S, Dezube BJ. Management of AIDS-related Kaposi's sarcoma. Lancet Oncol. 2007:8:167-76.

15. Schwartz RA, Lambert WC. Kaposi's Sarcoma. eMedicine Dermatology. [Jornal serial online]. [cited 2010 Jun 18]. Available from: http:// emedicine. com/ derm/ topic203.htm.

16. Ministério da Saúde. Secretaria de Vigilância em Saúde. Programa Nacional de DST e Aids. Recomendações para terapia anti-retroviral em adultos infectados pelo HIV: manual de bolso. Brasilia: Ministério da Saúde; 2008. p.151-95.

17. Bower M, Nelson M, Young AM, Thirlwell C, Newsom-Davis T, Mandalia S, et al. Immune reconstitution inflammatory syndrome associated with Kaposi's sarcoma. $J$ Clin Oncol. 2005;23:5224-8.

18. Reitz Jr MS, Gallo RC. Malignancies in human immunodeficiency virus infection. In: Mandell GL, Benett JE, Dolin R. Principles and Practice of Infectious Diseases. 6th ed. v. 2. Pennsylvania: Elsevier, Churchill Livingstone; 2005. p.1601-4.

MAILING ADDRESS:

Ricardo Montibeler Tiussi

Av. Hugo Viola, número 211 Apt. 303 bloco B

Jardim da Penba

29060420 Vitória, ES

E-mail: tiussiricardo@botmail.com

How to cite this article: Tiussi RM, Caus ALO, Diniz LM, Lucas EA. Sarcoma de Kaposi: clinical and pathological aspects in patients seen at the Hospital Universitário Cassiano Antônio Moraes - Vitória - Espírito Santo - Brazil. An Bras Dermatol. 2012;87(2):220-7. 